Байкальский государственный университет, г. Иркутск, Российская Федерация

О.А. Белых

Байкальский государственный университет, 2. Иркутск, Российская Федерация

\title{
ЭФФЕКТИВНОСТЬ ИНСТРУМЕНТОВ РЕАЛИЗАЦИИ ПРИНЦИПОВ УПРАВЛЕНИЯ ДЛЯ УСТОЙЧИВОГО ЛЕСОПОЛЬЗОВАНИЯ
}

\begin{abstract}
АННОТАЦИЯ. В статье обсуждаются инструменты регулирования системы устойчивого лесоуправления - критерии индикаторы и расчетная лесосека. Отмечается, что отсутствие методологии, четких законодательных актов, необходимых нормативов и инструментов, продолжают разрушать сложившуюся систему ведения лесного хозяйства; в итоге эта работа ведется несистемно и неэффективно. Проведенный анализ возможного использования критериев и индикаторов, разработанных международной группой с участием России для оценки лесоуправления показал, что они пока не получили необходимого применения, хотя набор критериев и индикаторов довольно близко отражает современные представления об устойчивом управлении лесными системами при условиях их практической адаптации к различным географическим условиям. Важнейшим инструментом, с точки зрения устойчивого управления лесами, является показатель расчетной лесосеки. Для выявления применимости существующего метода расчетной лесосеки в практическом использовании выполнен анализ его применения в лесном хозяйстве Иркутской области. Материалы лесоустройства, на основании которых исчислялась расчетная лесосека, устарели. Из базы расчета лесосеки не исключались леса, в которых режим пользования ограничен законодательно. В результате фактическая заготовка древесины от всех видов рубок в течение ряда лет составила менее половины расчетной лесосеки. Таким о6разом, Порядок расчетной лесосеки в Иркутской области не отражает реальной ситуации и требует пересмотра. кЛЮчЕВЫЕ словА. Устойчивое управление; лесное хозяйство; устойчивое лесопользование; критерии и индикаторы устойчивого управления лесами; расчетная лесосека.
\end{abstract}

ИНФОРМАЦИЯ О СТАТЬЕ. Дата поступления 19 декабря 2017 г.; дата принятия к печати 19 марта 2018 г.; дата онлайн-размещения 09 апреля 2018 г.

G. D. Rusetskaya

Baikal State University, Irkutsk, Russian Federation

O. A. Belykh

Baikal State University,

Irkutsk, Russian Federation

\section{EFFICIENCY OF TOOLS OF IMPLEMENTING GOVERNANCE POLICIES FOR SUSTAINABLE FOREST MANAGEMENT}

\begin{abstract}
The article considers the development issues of the electric power economy in the Baikal region as one of directions for implementing its geo-economic potential. The consistent integration of the region's energy system into the national and the international energy systems will facilitate the implementation of the regional natural and resource potential and the effective identification of its economy in the world geo-economic space. At the same time, the Baikal region is considered to be an integral transboundary territorial structure based on the basin approach, since it is the hydrosphere objects that form its economic landscape. The article also points out that
\end{abstract}

(ㄷ) Г. Д. Русеикая, О. А. Бельх, 2018

\section{Baikal Research Journal}


the further increase of the use of the regional hydro resources in the electric power industry is ecologically inexpedient or it even has reached its limit, since this adversely affects the ecosystem of the Baikal Basin and violates the principle of basin solidarity. It is reasonably proposed to develop the coal-fired generation based on ecologically safer water-coal fuel, as a measure for developing the regional electric power complex. KEYWORDS. Sustainable management; sustainable forestry; sustainable forest management; criteria and indicators for sustainable forest management; rated wood cutting area. ARTICLE INFO. Received December 06, 2017; accepted March 19, 2018; available online April 09, 2018.

Система управления природопользованием определяется поставленной целью и зависит от особенностей конкретной территории, наличия природных ресурсов и специфики их использования. Система при этом должна основываться на концепции устойчивого развития, определяющей регулирование потребления природных ресурсов настоящим поколением людей с учетом интересов будущих поколений, их использование, воспроизводство, поддержание соответствующего уровня жизни общества и сохранение окружающей среды ${ }^{1}$ [1-9]. Особая роль в этом отводится лесным ресурсам как первоначальному, природному капиталу. Нерациональное расходование этого капитала ведет к деградации ресурсов и утрате уникальных функций леса. Леса в силу своей полифункциональности играют определяющую роль в достижении также ряда других целей устойчивого развития, в том числе искоренение нищеты, обеспечение продовольственной безопасности, содействие устойчивому развитию сельского хозяйства и борьбе с изменением климата. Объем мировых лесных ресурсов продолжает сокращаться по мере роста народонаселения и перевода лесных угодий в земли сельскохозяйственного назначения. Однако, за последние 25 лет темпы чистого глобального облесения в мире сократилось более, чем на 50 \%. Этому способствует, совершенствование методов управления лесным хозяйством и все больший переход площадей в статус охраняемых ${ }^{2}$.

Декларация Всемирного лесного конгресса о перспективах лесов и лесного хозяйства до 2050 г. является важной вехой на пути достижения целей в области устойчивого развития на период до 2030 г. и создания устойчивого будущего. В послании Конгресса «Цели в области устойчивого развития (ЦУР)» речь также идет о необходимости устойчивого управления лесами. На современном этапе состояния лесных систем понятие «устойчивое управление лесами» перекликается с понятиями «устойчивое лесное хозяйство», «устойчивое лесопользование» .

Показатели состояния лесов по странам разнообразны в силу различных лесорастительных, климатических и экономических условий. Хотя цели и задачи управления лесным хозяйством в различных странах имеют свои специфические особенности, общим принципом современного лесоводства в Финляндии, Канаде, Швеции и др. является обеспечение экономической и экологической устойчивости лесопользования и сохранения социальных и культурных ценностей, прав и обязанностей, различных лесовладельцев в отношении лесопользования и сохранения лесных ресурсов [10-12].

При формировании политики устойчивого управления лесным хозяйством важное значение играет соотношение форм собственности на леса. Несмотря на их многообразие во многих странах государство контролирует состояние лесных ресурсов при помощи государственной системы инвентаризации лесов. Инвентаризационными работами охватываются все без исключения государственные, а

\footnotetext{
${ }^{1}$ Программа действий. Повестка дня на 21 век и другие документы конференции в Рио-де-अанейро в популярном изложении. Женева, 1993.

${ }^{2}$ XIV World Forestry Congress. Durban, South Africa. URL: http://www.fao.org/about/meetings/ world-forestry-congress/outcome.
}

\section{Baikal Research Journal}


также частные леса. Лесоустройство в государственных лесах проводится специализированными государственными лесоустроительными предприятиями.

В Канаде управление лесами формируется на уровне провинций, каждая из которых имеет свое законодательство, согласно которому собственником государственных лесов является министерство лесов провинций. Общее управление лесопользованием осуществляется федеративным правительством Канады, Министерством лесного хозяйства, правительством провинций. В общественном секторе сосредоточено $90 \%$ лесов, в частном - около 10 \%. Планирование объемов заготовок в арендных соглашениях производится на годовой и пятилетней основе. За недоруб и переруб расчетной лесосеки предусмотрены штрафные санкции. Расходы на лесовосстановление возмещаются владельцу лицензии двумя способами: прямым - в виде полной компенсации расходов в зависимости от условий лесоэксплуатации и возобновления леса и косвенным - за счет снижения размера арендной платы на величину затрат на восстановление. Размещение и доступность ресурсов - основные факторы дифференциации попенной платы, являющейся основой арендной платы в Канаде.

Финляндия, располагая лесными ресурсами на площади 23 млн га, что составляет 0,5 \% мировых лесных ресурсов, осуществляет: лесозаготовки $1,5 \%$, продукция лесной промышленности $-5 \%$, в экспорте печатных и писчих бумаг - $25 \%$ от мировых объемов производства лесопродукции. Успехи достигнуты при стабильном объеме лесозаготовок и неуклонном росте производительности лесов. Государственные леса находятся в управлении Лесной и парковой службы Финляндии. Парламент страны утверждает деятельность Лесной службы, задача которой - контроль за исполнением лесного и природоохранного законодательства, выдача лицензий на различные виды лесных пользований. Финское законодательство требует, чтобы рубки в частных лесах проводились только с разрешения государственных органов управления лесным хозяйством. Государственные органы лесного хозяйства ведут учет и изменения лесного фонда, проводя лесоинвентаризацию, оказывают финансовую поддержку субсидиями и льготными ссудами на проведение лесохозяйственных работ. Опыт Финляндии свидетельствует, что при четкой целенаправленной лесной политике с помощью гибкого законодательства и хозяйственно-административных решений можно установить систему управления лесным хозяйством, учитывающую и согласовывающую интересы всех субъектов лесных отношений.

Крупнейший в мире лесной сектор России имеет огромное национальное и мировое значение, в России по географическим условиям находятся значительные лесные ресурсы: из всего земельного фонда 94 \% покрыто растительностью, 70 \% составляет площадь лесного фонда ${ }^{3}$ [13]. Сложившаяся за более 200 -летний опыт введения лесного хозяйства и существовавшая до недавнего времени в России система управления лесами - результат длительного развития взаимоотношений между лесным хозяйством, лесоперерабатывающими отраслями промышленности, целлюлозно-бумажной, мебельной и другими секторами и потребителями. К сожалению, в настоящее время эта система разрушается, исходя из-за не совсем ясных политико-экономических интересов, что уже в ряде случаев катастрофически сказывается на состоянии лесного фонда ${ }^{4,5}$.

${ }^{3}$ Лесной план // Министерство лесного комплекса Иркутской области : офиц. сайт. URL: http:// irkobl.ru/sites/alh/documents/lesplan/.

${ }^{4}$ Лесной кодекс Российской Федерации [Электронный ресурс] : федер. закон от 04 дек. 2006 : (в ред. от 1 марта 2017 г.) // СПС «Консультант Плюс».

${ }^{5}$ Об утверждении Стратегии развития лесного комплекса Российской Федерации на период до 2020 г. [Электронный ресурс] : приказ Министерства промышленной торговли РФ № 482 от 31 окт. 2008 г. // СПС «Консультант Плюс».

\section{Baikal Research Journal}

электронный научный журнал Байкальского государственного университета 
Определяющим аспектом современного состояния лесного хозяйства и лесопользования России, является продолжающийся переход от директивной формы планирования и выполнения правительственных заданий, к рыночной экономике. Этот период характеризуется появлением новых форм лесопользования и ведения лесного хозяйства, при которых лесопромышленное производство и большая часть лесохозяйственный работ осуществляется частными предпринимателями или государственными предприятиями в соответствии с рыночными стимулами. Непосредственное управление лесами в России под контролем Рослесхоза осуществляют органы государственной власти субъектов РФ. Именно в их полномочия входит предоставление лесов в пользование, а также государственный лесной и пожарный надзор и контроль, управление лесами на землях собственности субъектов Российской Федерации. На местном уровне лесами управляют лесничества и лесопарки, а хозяйственную деятельность ведут арендаторы и специально созданные на базе бывших лесхозов хозяйственные структуры ${ }^{6}$ [14]. Такая организация управления и охраны лесов связана со значительными нарушениями и потерями в лесном фонде. Существовавшая до 2006 г. система лесной охраны полностью разрушилась, настоящей лесной охраны в большинстве регионов России просто нет.

В существующей нормативно-правовой ситуации только усугубляются проблемы: чрезмерной по интенсивности и бессистемной заготовки древесины при неэффективном лесовосстановлении, незаконных рубок, в том числе на землях сельскохозяйственного назначения; неограниченных рубок в защитных лесах и других запрещенных видах хозяйственной деятельности. Основной причиной отсутствия надлежащей реакции государства на экологические правонарушения в лесах является качество законодательства в соответствующей сфере ${ }^{7}$. Полное обновление российского лесного законодательства проходило с 2006 г. до настоящей времени, но не решило эти проблемы, наоборот - новые нормы закона признают нарушениями вполне логичные действия предприятий лесного сектора и часто, не дают наказать нарушителей. Кроме явных недостатков в законодательстве, путаницу вносят постоянные его изменения, в которых зачастую не ориентируются те, кто на основании этих норм должен выполнять свою работу. Охрану лесов по разным направлениям в России осуществляют разные организации. Уход за лесами и охрана от незаконных рубок остаются на совести арендаторов или организаций, созданных на базе бывших гослесхозов, которые через торги получают право вести хозяйственную деятельность на территории лесов [15, с. 312]. В итоге эта работа ведется несистемно и неэффективно. В российском лесном законодательстве декларируются принципы устойчивого управления лесами, сохранения биологического разнообразия лесов, сохранение других полезных функций лесных систем. Однако, не сложилась система управления для реализации этих принципов. Среди многих инструментов реализации принципов управления устойчивым лесным комплексом (внедрение современных промышленных технологий, выбор системы рубок и ухода за лесами и др.) необходимы критерии, определяющие стратегическое направление и основные пути практической деятельности в лесных системах на основе принятых принципов сохранения биоразнообразия, рационального, многоцелевого и неистощительного лесопользования. Соответствие критериев устойчивого управления лесами на уровне практического ведения лесного хозяйства может контролироваться и корректироваться по соответствующим индикаторам.

\footnotetext{
${ }^{6}$ Russia : forest policy during transition. Washington : World bank, 1997. $342 \mathrm{p}$.

${ }^{7}$ Кто отвечает за управление российскими лесами. Центр общественного мониторинга общероссийского народного фронта по проблеме экологии и защиты леса. М. : Общероссийский народный фронт, 2015. 68 с.
}

\section{Baikal Research Journal}

электронный научный журнал Байкальского государственного университета 
Начало формирования механизма устойчивого лесоуправления было заложено в документах «Повестка дня на XXI в.», «Принципы лесоводства» (1992 г. Риоде-Жанейро). Были провозглашены принципы, которые сыграли важнейшую роль в разработке практических подходов к ведению устойчивого лесного хозяйства и способствовали их последующему закреплению в национальных законодательствах 8 Позже принципы были отражены в межгосударственных критериях и индикаторах (КиИ). В 1995 г., в Женеве рабочая группа (представители Австралии, Канады, Чили, Китая, Японии, Республики Корея, Российской Федерации и США) по критериям и индикаторам рационального управления природоохранной ориентации для лесов умеренной и тропической зон утвердила комплексную систему критериев и индикаторов рационального лесоуправления природоохранной ориентации. Эти критерии представляют собой международную «точку отсчета» для оценки оптимальных методов управления и дальнейшей работы ${ }^{9}$.

Федеральная служба лесного хозяйства Российской Федерации в целях реализаций Концепции перехода к устойчивому развитию в части устойчивого лесоуправления приняла Концепцию устойчивого управления лесами РФ (1998 г.) и утвердила Критерии и индикаторы устойчивого управления лесами (КИУУЛ) Российской Федерации, предназначенные для оценки ситуации на национальном уровне $^{10}$. Этот документ базировался на КиИ для лесов Европы (Хельсинский процесс) и умеренных, и бореальных лесов мира (Монреальский процесс). Разработанные критерии охватывали выполняемые в лесах функции следующие направления:

- поддержание и сохранение продуктивной способности лесов;

- поддержание приемлемого санитарного состояния и жизнеспособности лесов;

- сохранение и поддержание защитных функций лесов;

- сохранение и поддержание биологического разнообразия лесов и их вклада в глобальный углеродный цикл;

- поддержание социально-экономических функций лесов;

- разработка инструментов лесной политики для устойчивого управления лесами.

В региональных рекомендациях критерии определены как стратегические направления практической деятельности для осуществления их принципов, как совокупность положений по ведению лесного хозяйства, следование которым обеспечивает устойчивое развитие; анализ изменений совокупности индикаторов с течением времени должен был стать одним из инструментов контроля за управлением лесами как на уровне страны в целом, так и на уровне субъекта или группы субъектов ${ }^{11,12,13}$ [16]. При сохранении разработанных критериев целесообразна их адаптация к региональным особенностям лесов в практике управления лесными системами. Критерии и индикаторы устойчивого управления лесами дают возможность проводить комплексную оценку состояния лесного фонда и осуществлять контроль за управлением лесами на уровне субъектов и страны в целом, они могут носить количественный или описательный характер. Результаты исследования по использованию КиИ для оценки состояния лесного

\footnotetext{
${ }^{8}$ Программа действий. Повестка дня на 21 век и другие документы конференции в Рио-де-Жанейро в популярном изложении. Женева, 1993.

${ }^{9}$ Russia : forest policy during transition. Washington : World Bank, 1997. $342 \mathrm{p}$.

${ }^{10}$ Критерии и индикаторы для сохранения и устойчивого управления умеренных и бореальных лесов. Монреальский процесс. М.: ВНИИЦ лесресурс, 1995. 25 с.

${ }^{11}$ Критерии и индикаторы устойчивого управления лесами на уровне лесоадминитративной единицы (лесхоза) в центральной и южной части Хабаровского края. Хабаровск, 1999. 39 с.

12 Об утверждении критериев и индикаторов устойчивого управления лесами Российской Федерации [Электронный ресурс] : приказ Рослесхоза от 5 февр. 1998 г. // СПС «КонсультантПлюс». (Документ опубликован не был).

13 Об утверждении Порядка исчисления расчётной лесосеки : приказ Рослесхоза от 27 апр. 2011 г. № 191. URL: http://docs.cntd.ru/document/902283266.
}

\section{Baikal Research Journal}


фонда частично по критерию и индикаторам «поддержание и сохранение продуктивной способности лесов» приведены в табл. 1.

Расчет индикаторов, позволяет определять процесс изменения лесных систем при хозяйственном освоении и степень их устойчивости. Для поддержания устойчивости природных систем необходимо, чтобы запасы ресурсов не уменьшались в долговременной перспективе, так как достижение устойчивости непосредственно связано с продуктивностью ресурсов леса.

Таблица 1

\section{Оценка состояния лесного фонда на основе критериев и индикаторов} устойчивого управления лесали

\begin{tabular}{|c|c|c|}
\hline Наименование критерия, индикатора & $\begin{array}{l}\text { Наличие показа- } \\
\text { теля в отчетности }\end{array}$ & \begin{tabular}{|c|} 
Условие устойчивости \\
природных систем
\end{tabular} \\
\hline \multicolumn{3}{|c|}{ Поддержание и сохранение продуктивной способности лесов } \\
\hline $\begin{array}{l}\text { 1. Изменение доли площади эксплуатационных } \\
\text { лесов относительно общей площади лесных зе- } \\
\text { мель (ежегодно) }\end{array}$ & + & $\begin{array}{l}\text { Увеличение } \\
\quad \geq 0\end{array}$ \\
\hline $\begin{array}{l}\text { 2. Изменение доли площади лесов, возможных } \\
\text { для эксплуатации, относительно площади по- } \\
\text { крытых лесом земель (ежегодно) }\end{array}$ & + & $\begin{array}{l}\text { Увеличение } \\
\quad \geq 0\end{array}$ \\
\hline $\begin{array}{l}\text { 3. Изменение площади доступных для освоения } \\
\text { эксплуатационных лесов относительно общей } \\
\text { площади лесов, возможных для эксплуатации: } \\
\text { древесных ресурсов }\end{array}$ & + & $\begin{array}{l}\text { Увеличение } \\
\quad \geq 0\end{array}$ \\
\hline $\begin{array}{l}\text { 4. Отношение допустимого (расчетного) и } \\
\text { фактически вырубаемого объема древесины в } \\
\text { эксплуатационных лесах по хвойному хозяйству } \\
\text { (ежегодно) }\end{array}$ & + & $100 \%$ \\
\hline $\begin{array}{l}\text { 5. Изменение доли площади покрытых лесом } \\
\text { лесных земель (ежегодно) }\end{array}$ & + & $\begin{array}{l}\text { Увеличение } \\
\quad \geq 0\end{array}$ \\
\hline $\begin{array}{l}\text { 6. Баланс среднего прироста и общего объема } \\
\text { вырубаемой древесины (ежегодно) }\end{array}$ & + & Равенство \\
\hline
\end{tabular}

Набор КиИ довольно близок и отражает современные представления об устойчивом лесоуправлении. Применение КиИ на практике во многом зависит от желания правительства конкретной страны их использовать и от общего уровня организации лесного хозяйства, а также от готовности его работников к восприятию нового [3]. Предполагалось, что по мере накопления данных по реализации лесной политики Российской Федерации на основе приведенных в Приказе федеральной службы лесного хозяйства критериев и индикаторов устойчивого управления лесами, внесения поправок и уточнения списка критериев возможна реализация устойчивого лесопользования, устойчивого управления лесными системами. Но концепция этого документа до настоящего времени не получила развития и практического использования в российской практике.

$\mathrm{C}$ точки зрения устойчивого управления лесами в настоящее время также одним из наиболее действенных инструментов считается порядок расчетной лесосеки. Размер расчетной лесосеки должен определяться в соответствии с лесохозяйственным регламентом и исчисляться по каждому лесничеству и лесопарку отдельно для эксплуатационных и защитных лесов по хозяйствам (хвойному, твердолиственному и мягколиственному) с распределением общего объема допустимого ежегодного изъятия древесины для каждого хозяйства по преобладающим породам на основании данных лесоустройства, государственного лесного реестра или специальных обследований лесов. В Порядке исчисления расчетной лесосеки, утвержденном приказом Рослесхоза от 27.05.2011 г. № 191, предусматривается

\section{Baikal Research Journal}


не только применимость расчетной лесосеки, и механизмы ее определения, но и даны конкретные формулы ее расчета ${ }^{14}$. Для определения оптимального размера расчетной лесосеки при сплошных рубках ее исчисление осуществляется по следующим показателям:

- лесосеки равномерного пользования;

- первой возрастной лесосеки;

- второй возрастной лесосеки;

- интегральной лесосеки;

- лесосеки по состоянию (в случаях, когда запас древесины поврежденных и усыхающих лесных насаждений соответствующей породы составляет более 50 \% общего запаса древесины спелых и перестойных лесных насаждений).

Расчетная лесосека, исчисленная по методу равномерного пользования, является оптимальной в лесах с относительно равномерным распределением площади лесных насаждений и запасов древесины соответствующего хозяйства по группам возраста. Первая возрастная лесосека является оптимальной в хозяйствах с истощенными запасами древесины спелых и перестойных лесных насаждений (менее 20 \% от общего запаса древесины в лесных насаждениях соответствующего хозяйства). Расчетная лесосека, исчисленная методами второй возрастной и интегральной лесосеки, является оптимальной в лесах, где запасы древесины спелых и перестойных лесных насаждений составляют более 50 \% от общего запаса древесины в соответствующих хозяйствах. При заготовке древесины спелых и перестойных лесных насаждений выборочными рубками, а также при заготовке древесины при вырубке погибших и поврежденных лесных насаждений, при уходе за лесом расчетная лесосека исчисляется исходя из интенсивности рубки (процент изымаемого за один прием рубки запаса древесины) и периодов повторения приемов рубок. Оптимальная расчетная лесосека не должна быть меньше расчетной лесосеки, исчисленной методом лесосеки по состоянию, и больше размера общего среднего прироста древесины лесных насаждений соответствующего хозяйства и преобладающих пород. В хозяйствах с истощенными запасами древесины спелых и перестойных лесных насаждений расчетная лесосека должна обеспечивать использование запасов древесины хвойных и твердолиственных лесных насаждений семенного происхождения за период не менее 10 лет, а мягколиственных насаждений — не менее 5 лет. В отдельных случаях в качестве оптимального может приниматься размер расчетной лесосеки, имеющий промежуточное значение между размерами, исчисленными разными методами, если он наиболее полно отвечает условиям обеспечения: многоцелевое, рациональное, непрерывное, неистощительное использование лесов, исходя из установленных возрастов рубок, сохранение биологического разнообразия, водоохранных, защитных и иных полезных свойств лесов.

Все способы определения расчетной лесосеки, предусмотренные Порядком исчисления расчетной лесосеки ${ }^{15}$, при определенных условиях обеспечивают быстрое истощение древесных ресурсов в транспортнодоступных местах. Наибольшую неопределенность в структуре расчетной лесосеки создают экономически недоступные леса, а экономическая доступность или недоступность того или иного леса для лесопользования зависит от экономической ситуации в стране, состояния лесной отрасли, лесного рынка, цен на топливо, наличия государственной поддержки, строительства лесных дорог и множества других обстоятельств. Прогнозировать их на более или менее длительный срок в отечественных условиях практически нереально. На практике недостаточно учитывается, что лесные участки могут иметь

14 Об утверждении Порядка исчисления расчётной лесосеки : приказ Рослесхоза от 27 апр. 2011 г. № 191. URL: http://docs.cntd.ru/document/902283266.

15 Там же.

\section{Baikal Research Journal}

электронный научный журнал Байкальского государственного университета 
различную исходную возрастную и породную структуру насаждений, например, леса урегулированные, относительно равномерно распределенные по возрасту, леса с дефицитом спелых древостоев и т. д. Применяемые на практике методы расчета недостаточно учитывают изменение возрастной и породной структуры насаждения в процессе лесопользования, а также процессы лесовосстановления, вероятные потери от пожаров, повреждения вредителями и болезнями, и пр. [17].

Для выявления применимости существующего Порядка расчетной лесосеки в практическом использовании выполнен анализ ее применения в лесном хозяйстве Иркутской области. Покрытые лесной растительностью земли в Иркутской области занимают 64,3 млн га, что составляет 90 \% суммарной площади земель лесного фонда и лесов, расположенных на землях иных категорий. Древостой представлен с преобладанием основных лесообразующих пород (58,9 млн га или 91,7 \%) и кустарниковыми зарослями - 5,3 млн га или 8,3 \%. Распределение площади лесов области по целевому назначению: защитные леса занимают - 21,9\% их общей площади, эксплуатационные леса - 46,7 \% и резервные леса - 31,4 \%. Резервные леса расположены лишь на землях лесного фонда, эксплуатационные - на землях лесного фонда и на землях обороны и безопасности, защитные леса - на землях всех категорий16. Спелые и перестойные деревья занимают почти половину лесной площади и характеризуются крупномерностью. Запас древесины на 1 га превышает 160 м $^{3}$. Среднегодовой прирост древесины на территории Иркутской области оценивается в 1,4 $\mathrm{m}^{3}$ на 1 га. Это меньше, чем в регионах с благоприятными почвенно-климатическими условиями и высоким уровнем развития лесного хозяйства как за рубежом, так и в пределах России. Пригодные к рубке лесные массивы размещены по территории области крайне неравномерно. В местах традиционных лесозаготовок вдоль транссибирской железнодорожной магистрали, вокруг Братского водохранилища лесосырьевые ресурсы истощены; в северных и восточных районах области лесоэксплуатация развита недостаточно, здесь наблюдается преобладание спелых и перестойных насаждений. Отсутствие достоверной информации о состоянии лесного фонда на значительной части территории Иркутской области препятствует организации неистощительного пользования лесов.

В 2014-2016 гг. ежегодный допустимый объем изъятия древесины при всех видах рубок - расчетная лесосека по лесничествам лесного хозяйства Иркутской области - составляет 72,8 млн м $^{3}$. Это означает, что столько лесных насаждений разрешается вырубить за год во всех лесничествах области. Учтенный объем заготовки древесины от всех видов рубок по лесному хозяйству Иркутской области составил в 2015 г. 34,2 млн $\mathrm{M}^{3}$.

В таблице 2 представлена динамика объемов допустимого изъятия древесины и фактического их использования в границах лесного хозяйства Иркутской области в период 2011-2015 гг. В данный период использование расчетной лесосеки от всех видов рубок составило 38,0-47,0 \%. Данные расчетной лесосеки показывают, что в лесах Иркутской области есть большие резервы для развития лесной промышленности без истощения лесов, однако, уже на сегодняшний день, некоторые лесничества Иркутской области (Иркутское, Тулунское, Заларинское, Куйтунское, Осинское, Кировское), испытывают недостаток в спелых насаждениях. Это связано, с тем, что на территории вышеуказанных лесничеств не проводится лесоустройство. Материалы лесоустройства на основании которых исчислялась расчетная лесосека устарели. Средняя давность проведения лесоустройства по области в настоящее время составляет около 30 лет. Произошедшие изменения за это время не нашли отражение в лесной статистике.

${ }^{16}$ Лесной план // Министерство лесного комплекса Иркутской области : офиц. сайт. URL: http:// irkobl.ru/sites/alh/documents/lesplan/.

\section{Baikal Research Journal}

электронный научный журнал Байкальского государственного университета 
Таблица 2

Диналика объемов допустилого изъятия древесины и фактического их использования в границах лесного хозяйства Иркутской области (2011-2015 г2.)

\begin{tabular}{|c|c|c|c|c|c|c|c|c|c|c|}
\hline \multirow[b]{2}{*}{$\begin{array}{c}\text { Наименова- } \\
\text { ние }\end{array}$} & \multicolumn{2}{|c|}{2011 г. } & \multicolumn{2}{|c|}{2012 г. } & \multicolumn{2}{|c|}{2013 г. } & \multicolumn{2}{|c|}{2014 г. } & \multicolumn{2}{|c|}{2015 г. } \\
\hline & Всего & $\begin{array}{l}\text { В т. ч. } \\
\text { по хвой- } \\
\text { ному хо- } \\
\text { зяйству }\end{array}$ & Всего & $\begin{array}{l}\text { В т. ч. } \\
\text { по хвой- } \\
\text { ному хо- } \\
\text { зяйству }\end{array}$ & Всего & $\begin{array}{l}\text { В т. ч. } \\
\text { по хвой- } \\
\text { ному хо- } \\
\text { зяйству }\end{array}$ & Всего & $\begin{array}{c}\text { В т. ч. } \\
\text { по хвой- } \\
\text { ному хо- } \\
\text { зяйству }\end{array}$ & Всего & $\begin{array}{l}\text { В т. ч. } \\
\text { по хвой- } \\
\text { ному хо- } \\
\text { зяйству }\end{array}$ \\
\hline $\begin{array}{l}\text { Допусти- } \\
\text { мый объем } \\
\text { изъятая } \\
\text { древесины } \\
\text { (расчетная } \\
\text { лесосека) } \\
\text { всего в } \\
\text { тыс. } \text { м }^{3}\end{array}$ & 68602,4 & 47851,3 & 71531,8 & 49822,2 & 71531,8 & 49822,2 & 72807,8 & 50892,4 & 72807,8 & 50892,4 \\
\hline $\begin{array}{l}\text { в т. ч. } \\
\text { расчетная } \\
\text { лесосека } \\
\text { от рубок } \\
\text { спелых и } \\
\text { перестой- } \\
\text { ных лесных } \\
\text { насаждений }\end{array}$ & 55413,3 & 36200,8 & 58769,1 & 38360,1 & 58769,1 & 38360,1 & 58769,1 & 38360,1 & 58769,1 & 38360,1 \\
\hline $\begin{array}{l}\text { Фактиче- } \\
\text { ски заго- } \\
\text { товлено от } \\
\text { всех видов } \\
\text { рубок, в } \\
\text { тыс. } \text { м }^{3}\end{array}$ & 26075,6 & 22335,0 & 25134,0 & 21684,8 & 26888,3 & 23398,9 & 29185,2 & 24905,5 & 34172,3 & 28732,3 \\
\hline $\begin{array}{l}\text { В т. ч. фак- } \\
\text { тически } \\
\text { заготовле- } \\
\text { но от рубок } \\
\text { спелых } \\
\text { и пере- } \\
\text { стойных } \\
\text { лесных на- } \\
\text { саждений, } \\
\text { в тыс. м }\end{array}$ & 17376,6 & 14119,9 & 18963,5 & 15966,6 & 20044,4 & 16981,0 & 21849,0 & 17962,9 & 26354,4 & 21342,6 \\
\hline $\begin{array}{l}\text { Процент } \\
\text { исполь- } \\
\text { зования } \\
\text { расчетной } \\
\text { лесосеки от } \\
\text { всех видов } \\
\text { рубок }\end{array}$ & 38,0 & 46,7 & 35,1 & 43,5 & 37,6 & 46,9 & 40,0 & 48,9 & 47,0 & 56,0 \\
\hline $\begin{array}{l}\text { Процент } \\
\text { исполь- } \\
\text { зования } \\
\text { расчетной } \\
\text { лесосеки } \\
\text { от рубок } \\
\text { спелых и } \\
\text { перестой- } \\
\text { ных лесных } \\
\text { насаждений }\end{array}$ & 31,4 & 39,0 & 32,3 & 41,6 & 34,1 & 44,3 & 37,2 & 46,8 & 45,0 & 56,0 \\
\hline
\end{tabular}

\section{Baikal Research Journal}


Ситуация с лесоустройством означает, что база для исчисления расчетной лесосеки в среднем по области отражает ту ситуацию, которая была три десятилетия назад. За этот период было много вырублено леса, повреждено вредителями или сгорело. Кроме того, есть леса, в которых режим пользования официально ограничен, но они не исключены из базы для определения расчетной лесосеки (например, региональные заказники). Есть леса, в которых режим пользования должен быть ограничен по законодательству, но официально они не выделены (водоохранные зоны вдоль рек, ручьев и озер). Расчетная лесосека определяется на основании данных о современной структуре земель лесного фонда без учета данных о приросте лесов. Во многих случаях расчетная лесосека может существенно превышать этот прирост. Таким образом, ориентация на экстенсивную модель использования лесных ресурсов, то есть на полное использование расчетной лесосеки во многих случаях автоматически приведет к истощительному лесопользованию и быстрому сокращение доступных лесов Иркутской области. В настоящее время в целях реализации ст. 29.1, ст. 30 ЛК РФ, с большим трудом подбираются лесные насаждения, имеется «дефицит» в лесных насаждениях. Некоторые арендаторы лесных участков с трудом набирают лесосечный фонд на срок действия проектов освоения лесов. Расчетная лесосека на несколько десятилетий не может быть достоверной. Таким образом, размер расчетной лесосеки в Иркутской области - это административная величина, хотя и рассчитываемая по установленному методу, в действительности не соответствует реальной ситуации в лесах, не отражает возможные объемы заготовки древесины.

\section{Выводы}

В числе инструментов реализации принципов устойчивого управления лесными системами необходимо использование критериев, определяющих стратегические направления практической деятельности, отвечающих принципам, заложенным в лесной политике страны. Через анализ изменяющихся индикаторов в соответствии с региональными особенностями лесов с течением времени возможна оценка критериев, характеризующих в целом состояние и восстановление разрушенных лесных систем, сохранение биоразнообразия и поддержание продуктивной, защитной, социально-экономический и др. функции лесов, и контроля эффективности управления лесами на всех уровнях.

Порядок расчетной лесосеки не соответствует критериям и индикаторам устойчивого лесопользования. Исчисление расчетных лесосек как инструмента эффективного лесоуправления требует пересмотра и разработки новых подходов к определению ежегодно допустимых объемов изъятия древесины на основе биологической модели роста деревьев, обеспечивающих реальную неистощительность лесопользования, с учетом возраста, когда средний ежегодный прирост достигает максимальной величины, закономерностей строения и развития древостоев и количества потребности в древесине.

\section{Список использованной литературы}

1. Бобылев С. Н. Экономика природопользования : учебник / С. Н. Бобылев, А. Ш. Ходжиев. - М. : Инфа-М, 2004. - 567 с.

2. Данилов-Данильян В. И. Экологический вызов и устойчивое развитие / В. И.ДаниловДанильян, К.С. Лосев. - М. : Прогресс-Традиция, 2001. - 416 с.

3. Основы устойчивого лесоуправления: учебное пособие для вузов. / М. Л. Коропаческий, [и др.] ; под ред. А. В. Беляковой, Н. М. Шматоковой. - 2-е изд. перераб. - M. : WWF России, 2014. - 266 с.

4. Русецкая Г. Д. Концептуальные основы стратегии устойчивого развития : учеб. пособие / Г. Д. Русецкая. - Иркутск : Изд-во ИГЭА, 1999. - 21 с.

\section{Baikal Research Journal}


5. Русецкая Г. Д. Основы управления биологическими и технологическими системами в лесном и лесопарковом хозяйстве : учеб. пособие / Г. Д. Русецкая. - Иркутск : Изд-во БГУЭП, 2014. - 182 с.

6. Русецкая Г. Д. Устойчивое управление, экологические законы и проблемы лесных систем / Г. Д. Русецкая // Известия ИГЭА. - 2015. - Т. 25, № 3. - С. 408-414.

7. Pearee D. Blueprint for a Sustainable economy / D. Pearee, E. Barbier. - London : Earthscan, 2000. - 243 p.

8. Schmidhieny S. Changing Course. A global Business Perspective on Development and Environment / S. Schmidhieny. - London : MJT Press, 1994. - 356 p.

9. Tietenberg T. H. Environmental and natural resource economics / T. H. Tietenberg. 5th ed. - Boston : Addison-Wesley, 2000. - 592 p.

10. Николайчук А. А. Зарубежный опыт государственного регулирования лесных ресурсов / А. А Николайчук, О. А. Николайчук // Проблемный анализ и государственноуправленческое проектирование. - 2013. - № 3 (29). - С. 103-114.

11. Примеры зарубежного опыта устойчивого лесоуправления и лесопользования : сб. статей / под ред. Н. Шматкова. - М. : WWF России, 2012. - 180 с.

12. Ферару Г. С. Устойчиво развитие предприятий ЛПК как эколого-экономических систем / Г. С. Ферару. - Saarbrucken : Lap Lambert academic publishing, 2011. — 312 c.

13. Морозов Г. Ф. Учение о лесе. Избранные труды / Г. Ф. Морозов. - М. : Лесная промышленность, 1970. - 27 с.

14. Белых О. А. Региональные ресурсы полезных растений для экономики / О. А. Белых / Известия Иркутской государственной экономической академии (Байкальский государственный университет экономики и права). - 2012. - № 1. - Режим доступа: http://brj-bguep.ru/reader/article.aspx $? \mathrm{id}=14240$.

15. Дицевич Я. Б. Противодействие преступности в сфере лесопользования: проблемы и перспективы / Я. Б. Дицевич, О. А Белых, Г. Д. Русецкая // Всероссийский криминологический журнал. - 2017. - Т. 11, № 2. - С. 308-317. — DOI 10.17150/25004255.2017.11(2).308-317.

16. Исаев А. С. Актуальные проблемы национальной лесной политики / А. С. Исаев, Г. Н. Коровин. - М. : Типография Левко, 2009. - 108 с.

17. Соколов В. А. О методике исчисления расчетных лесосек / В. А. Соколов, В. Ф. Багинский // Сибирский лесной журнал. - 2014. - № 5- С. 9-15.

\section{References}

1. Bobylev S. N. Khodzhiev A. Sh. Ekonomika prirodopol'zovaniya [Environmental economics]. Moscow, Infa-M Publ., 2004. 567 p.

2. Danilov-Danil'yan V. I., Losev K. S. Ekologicheskii vyzov i ustoichivoe razvitie [Ecological challenge and sustainable development]. Moscow, Progress-Traditsiya Publ., 2001. 416 p.

3. Koropacheskii M. L., Teplyakov V. K., Yanitskaya T. O. [et al] ; Belyakova A. V., Shmatokova N. M.(eds). Osnovy ustoichivogo lesoupravleniya: uchebnoe posobie dlya vu-zov [Basics of sustainable forest management]. $2^{\text {nd }}$ ed. Moscow, WWF Rossii Publ., 2014. 266 p.

4. Rusetskaya G. D. Kontseptual'nye osnovy strategii ustoichivogo razvitiya [Conceptual bases of sustainable development strategy]. Irkutsk State Economics Academy Publ., 1999. 21 p.

5. Rusetskaya G. D. Osnovy upravleniya biologicheskimi i tekhnolo-gicheskimi sistemami $v$ lesnom $i$ lesoparkovom khozyaistve [Bases of managing biological and technological systems in forestry and forest parks]. Irkutsk, Baikal State University of Economics and Law Publ., 2014. 182 p.

6. Rusetskaya G. D. Sustainable management, environmental laws and forest systems problems. Izvestiya Irkutskoi gosudarstvennoi ekonomicheskoi akademii = Izvestiya of Irkutsk State Economics Academy, 2015, vol. 25, no. 3, pp. 408-414. (In Russian). $243 \mathrm{p}$

7. Pearee D., Barbier E. Blueprint for a Sustainable economy. London, Earthscan, 2000.

8. Schmidhieny S. Changing Course. A global Business Perspective on Development and Environment. London, MJT Press, 1994. 356 p.

9. Tietenberg T. H. Environmental and natural resource economics. $5^{\text {th }}$ ed. Boston, Addison-Wesley, 2000. 592 p.

\section{Baikal Research Journal}


10. Nikolaychuk A. A., Nikolaychuk O. A. Foreign Experience of Handling of Forest Resources. Problemnyi analiz $i$ gosudarstvenno-upravlencheskoe proektirovanie $=$ Problem Analysis and Public Administration Projection, 2013, no. 3 (29), pp. 103-114. (In Russian).

11. Shmatkov N. (ed.). Primery zarubezhnogo opyta ustoichivogo le-soupravleniya $i$ lesopol'zovaniya [Examples of foreign experience of sustainable forest management and timber exploitation]. Moscow, WWF Rossii Publ., 2012. 180 p.

12. Feraru G. S. Ustoichivo razvitie predpriyatii LPK kak ekologo-ekonomicheskikh sistem [Sustainable development of forestry enterprises as ecological and economic systems] Saarbrucken, Lap Lambert academic publishing, 2011. 312 p.

13. Morozov G. F. Uchenie o lese. Izbrannye trudy [Doctrine of forest. Selected Works]. Moscow, Lesnaya promyshlennost Publ., 1970. 27 p.

14. Belykh O. A. Regional usful plants resources for economy. Izvestiya Irkutskoy gosudarstvennoy ekonomicheskoy akademii (Baykalskiy gosudarstvennyy universitet ekonomiki $i$ prava) = Izvestiya of Irkutsk State Economics Academy (Baikal State University of Economics and Law), 2012, no. 1. Available at: http://brj-bguep.ru/reader/article.aspx?id=14240. (In Russian).

15. Ditsevich J. B., Belykh O. A., Rusetskaya G. D. Counteracting Crimes in the Sphere of Forest Resources' Use: Problems and Perspectives. Vserossiiskii kriminologicheskii zhurnal = Russian Journal of Criminology, 2017, vol. 11, no. 2, pp. 308-317. DOI 10.17150/25004255.2017.11(2).308-317. (In Russian).

16. Isaev A. S. Korovin G. N. Aktual'nye problemy natsio-nal'noi lesnoi politiki [Topical problems of national forest policy]. Moscow, Tipografiya Levko Publ., 2009. 108 p.

17. Sokolov V. A., Baginski V. F. On the methods for calculating annual allowable cut. Sibirskii lesnoi zhurnal = Siberian Journal of Forest Science, 2014, no. 5, pp. 9-15. (In Russian).

\section{Информация об авторах}

Русеикая Генриетта Денисовна - доктор технических наук, профессор, кафедра экономики и управления бизнесом, Байкальский государственный университет, 664003, г. Иркутск, ул. Ленина, 11, e-mail: rusetskaya2010@yandex.ru

Бельх Ольга Александровна - доктор биологических наук, профессор, кафедра налогов и таможенного дела, Байкальский государственный университет, 664003, г. Иркутск, ул. Ленина, 11, e-mail: belykh-oa@bgu.ru.

\section{Authors}

Genrietta D. Rusetskaya - Doctor habil. in Engineering, Professor, Chair of Economics and Business Administration, Baikal State University, 11 Lenin St., 664003, Irkutsk, e-mail: rusetskaya2010@yandex.ru

Olga A. Belykh - Doctor habil. in Biology, Associate Professor, Chair of Taxes and Customs Regulation, Baikal State University, 11 Lenin St., 664003, Irkutsk, e-mail: belykh-oa@bgu.ru.

\section{Для цитирования}

Русецкая Г. Д. Эффективность инструментов реализации принципов управления для устойчивого лесопользования / Г. Д. Русецкая, О. А. Белых // Baikal Research Journal. 2018. - T. 9, № 1. - DOI : 10.17150/2411-6262.2018.9(1).7.

\section{For Citation}

Rusetskaya G. D., Belykh O. A. Efficiency of Tools of Implementing Governance Policies for Sustainable Forest Management. Baikal Research Journal, 2018, vol. 9, no. 1. DOI: 10.17150/2411-6262.2018.9(1).7. (In Russian).

\section{Baikal Research Journal}

